\title{
THE ROYAL COMPONENTS OF MELCHIZEDEK IN HEBREWS 7
}

\author{
DAE-I KANG ${ }^{*}$ \\ Golden Gate Baptist Theological Seminary
}

\begin{abstract}
The royal component of Melchizedek in Hebrews 7 has often been disregarded. This study investigates the royal component of Melchizedek in Hebrews 7 through the research of the divine kingship in the Ancient Near East and the royal components of Melchizedek in Genesis 14, Psalm 110, and the Second Temple writings. The images of divine kingship in the Ancient Near East continue in Psalm 110 and Hebrews 7. There is not only the priestly but also the royal image of Melchizedek in Genesis 14, Psalm 110, and the Second Temple writings. Based on the research, the royal components of Melchizedek in Hebrews 7 can be drawn. It is evident that the author of Hebrews focused on the superior priesthood of Christ by using Melchizedek as a model for Christ in Hebrews 7. As the priesthood of Melchizedek is a royal priesthood, the priesthood of Christ is also a royal priesthood. Therefore, the royal priesthood should not be neglected in Hebrews 7.
\end{abstract}

KEY WORDS: Melchizedek, Hebrews 7, Psalm 110, Genesis 14, Royal priesthood

\section{Introduction}

In Hebrews, Jesus is called "Christ", "Lord", "great shepherd", "apostle", "pioneer", "Son", "Son of God", "priest", and "high priest", with "high priest" considered to be the key motif. ${ }^{1}$ Hebrews never uses "king" to describe Jesus, thus the motif of the kingship of Jesus has often been overlooked. However, the kingship motif can be found throughout Hebrews, even with Melchizedek.

Melchizedek is mentioned only in Genesis 14:18-20 and Psalms 110:4 in the Old Testament and in Hebrews 5:6-7, 6:20 and 7 in the New Testa-

* DAE-I KANG is PhD (ABD) student of the Biblical Studies at Golden Gate Baptist Theological Seminary. He is also lecturer of the Biblical Studies at Korea Evangelical Seminary, South Korea.

1 Eric F. Mason, "You Are a Priest Forever". Second Temple Jewish Messianism and the Priestly Christology of the Epistle to the Hebrews (Leiden: Brill, 2008), 7. 
ment. According to Genesis 14:18-20, Melchizedek is not only the king of Salem, but also the priest of God. Even though Melchizedek is the king, according to D. W. Rooke, "[t]he royal component of Melchizedek's identity is a factor which is often overlooked in the interpretation of Hebrews 7". ${ }^{2}$ I agree with Rooke. For example, as for the reason the author of Hebrews chose Melchizedek rather than Reuel/Jethro or some other non-Israelite priest as the type of Christ, Fred L. Horton says it is because "Melchizedek is the first priest mentioned in the Torah". ${ }^{3}$ F. F. Bruce says that the author of Hebrews speaks of Melchizedek "[i]n order to draw out the significance of Christ's being acclaimed as perpetual high priest 'after the order of Melchizedek'," and Craig R. Koester says that Hebrews 7 "demonstrates that Christ is the priest after the type of Melchizedek" most scholars focus only on Melchizedek as priest, but they have not paid much attention to the royal component of Melchizedek's identity.

The purpose of this paper is to investigate the royal component of Melchizedek in Hebrews 7 by examining the concept of divine kingship in the Ancient Near East and the royal component of Melchizedek in the Old Testament and the Second Temple writings such as Philo, Josephus, the Qumran Scrolls, and the Old Testament Pseudepigrapha. This investigation is presented in four steps. First, I will consider the concept of divine kingship in the Ancient Near East, focusing on Egypt, Babylon, Ugarit, and the Hittite kingdom. Second, I will search for the royal component in Genesis 14 and Psalm 110. I will deal especially with the context of these passages because the royal component of Melchizedek can be understood more effectively through that context. Third, I will examine the royal component of Melchizedek in non-biblical writings: the works of Philo and Josephus, the Qumran Scrolls, and the Old Testament Pseudepigrapha. As I examine them, I will try to compare them with the letter to the Hebrews. Fourth, I will scrutinize the royal components of Melchizedek in Hebrews 7. Through this process, I will show that the royal components of Melchizedek indeed exist in Hebrews 7 and should not be overlooked. Moreover, I will argue

2 D. W. Rooke, "Jesus as Royal Priest: Reflections on the Interpretation of the Melchizedek Tradition in Hebrews 7", Biblica 81.1 (2000): 84.

3 Fred L. Horton Jr., The Melchizedek Traditions. A Critical Examination of the Sources to the Fifth Century $A D$ and in the Epistle to the Hebrews (Cambridge: Cambridge University Press, 1976), 157.

4 F. F. Bruce, The Epistle to the Hebrews (Grand Rapids, MI: Eerdmans, 1990), 156.

$5 \quad$ Craig R. Koester, Hebrew. A New Translation with Introduction and Commentary, The Anchor Bible, vol. 36 (New York: Doubleday, 2001), 336.

PERICHORESIS $10.1(2012)$ 
that the author of Hebrews chose Melchizedek in Hebrews 7 because of his royal priesthood. Finally, I will investigate the ways in which the combined character of the priest and the king can be found throughout the Hebrews. It will reinforce that the author of the Hebrews was keeping in mind that Christ is not only a priest, but also a king and that his priesthood is a royal priesthood.

\section{Divine Kingship in the Ancient Near East}

Ivan Engnell studied divine kingship in the Ancient Near East in depth. According to him, in ancient Egypt ${ }^{6}$ and Babylon ${ }^{7}$ kings had a divine origin. Thus, the king was "described as the one who has neither father nor mother". The king was also considered to be chosen by god not only "at the moment of conception" but also even "long before birth".9 In the Hittite and Ugaritic cultures, although the king was not of divine origin, he was described as the son of god. ${ }^{10}$

The king was also considered to be identical with the gods. In ancient Egypt, the king was identical not only with Re, the sun-god, but also with Horus, the son of Osiris who was a god related to fertility. ${ }^{11}$ In Babylon the king was also identical with "the deity of vegetation". ${ }^{12}$ The king's identity as connected with god caused his significant role in the cult. "In the cult, the king functions as high priest in the cult par excellence".${ }^{13}$ In ancient Egypt the king functioned as a high priest not only "in the daily cult" but also "at the great festivals", ${ }^{14}$ while in Babylon the king's ritual function related mainly to the temple-building and the enthronement festival. ${ }^{15}$ In Hittite culture, the king as the high priest ${ }^{16}$ maintained the cult and appointed the priests. ${ }^{17}$

6

7

8

9

10

11

12

13

14
Ivan Engnell, Studies in Divine Kingship in the Ancient Near East (Oxford: Basil Blackwell, 1967), 4.

Ibid., 16.

Ibid., 4.

Georges Contenau, Everyday Life in Babylon and Assyria (New York: St. Martin's Press, 1954), 115.

Engnell, Divine Kingship, 58, 80 .

Ibid., 6-10.

Ibid., 30 .

Ibid., 5 .

Ibid., 5 .

Ibid., 32.

O. R. Gurney, Some Aspects of Hittite Religion (Oxford: Oxford University Press, 1976), 1.

Engnell, Divine Kingship, 62. 
David Toshio Tsumura reveals that the king in Ancient Ugarit played sacral roles in "the monthly dynastic rituals", "the royal funerary ritual", and "the national fertility cult". ${ }^{18}$

In the Ancient Near East the king was considered to be the perfect ruler of the country. Divine power was endowed on the king "with every perfection from before his birth". ${ }^{19}$ Among those powers, which are endowed to the king, "strength and understanding" were most important. ${ }^{20}$ In Babylon, the king was described as a victorious warrior who defeated the enemies. To his own soldiers the king was regarded as "a wall, shield, and fortress, spring and shadow". ${ }^{21}$ Socially, the king was also reckoned to be the "administer of justice". Thus he was called "the good shepherd" by his country, "a father" by the widow and the orphan, and "a refuge" by the homeless.22 Righteousness and peace were two of most important characteristics of divine kingship in the Ancient Near East. For example, Neriglissar, king of Babylon, said, "Righteousness in the country I made to dwell, my widespread people in peace I governed" (italics mine). ${ }^{23}$

\section{Genesis 14}

The brief story of Genesis 14 is as follows. Amraphel, king of Shinar, Arioch, king of Ellasar, Kedorlaomer, king of Elam and Tidal, king of Goiim warred against Bera, king of Sodom, Birsha, king of Gomorrah, Shinab, king of Admah, Shemeber, king of Zeboiim, and the king of Bela (verses 1-4). The former kings defeated the latter kings (verses 5-11), and at that time, Lot, who was living in Sodom, was carried off (verse 12). Hearing Lot's had been taken captive, Abram, with 318 trained men, recovered all the goods and brought back Lot and his possessions (verses 13-16). When he returned (verse 17), he encountered Melchizedek, king of Salem, priest of God. Melchizedek blessed Abram, and Abram gave a tithe to Melchizedek (verses 1820). The king of Sodom offered the goods to Abram, but Abram declined them (verses 21-24).

18 David Toshio Tsumura, "King and Cults in Ancient Ugarit", ed. by Kazuko Watanabe Priests and Officials in the Ancient Near East (Heidelberg: Universitätsverlag C. Winter, 1999), 216.

Contenau, Babylon and Assyria, 117.

Ibid., 117.

Engnell, Divine Kingship, 12.

Ibid., 12.

S. Langdon, Die Neubabylonischen Königsinschriften, Vorderasiatische Bibliothek 4 (Leipzig: J. C. Hinrichs, 1912), 104. 23f, quoted in Engnell, Divine Kingship, 43.

PERICHORESIS 10.1 (2012) 
Genesis 14 can be divided into two parts, with the overall structure as follows:

verses 1-16 Three battle reports:

1-4 Eastern kings vs. Westerners: round 1

5-12 Eastern kings vs. Westerners: round 2

13-16 Abram vs. Eastern kings ${ }^{24}$

verses 17-24 Confrontation between Abram, the king of Sodom, and Melchizedek:

17 King of Sodom meets Abram

18-20 Melchizedek, King of Salem, blesses Abram

21-24 King of Sodom's offer and Abram's reply

The structure of the second part (verses 17-24) is inclusio. The interaction between Abram and Melchizedek is centered, and the confrontation between Abram and the king of Sodom functions as a bracket. Genesis 14:1820 seems to be inserted later because it does not flow naturally within the context. Considering the circumstances, there seems to be a discontinuity between Genesis 14:18-20 and its context. This proposes a very debatable issue $^{25}$ which I will not discuss in this paper, since I will discuss the passage based only on the final form of the text.

We can now go to the more detailed structure of verses 18-20:

$\begin{array}{ll}\text { A verses 18-19a } & \text { Melchizedek gives Abram bread and wine } \\ \text { X verses 19b-20a } & \text { Melchizedek blesses Abram (poetry) } \\ \text { A' verse 20b } & \text { Abram gives Melchizedek a tithe }\end{array}$

The structure of verses 18-20 is also framed by an inclusion. As Melchizedek gives Abram bread and wine in verses 18-19a, Abram gives Melchizedek a tithe in verse 20b. The blessing Melchizedek gives to Abram, which is poet1 (Dallas, TX: Word, 2002), 304.

25 While Nahum Sarna and Gordon J. Wenham consider the literary integrity of Genesis 14, Fitzmyer and Gerhard von Rad regard that Genesis 14:18-20 was inserted in the account of Abram's meeting with the king of Sodom; Nahum Sarna, Genesis, JSP Torah Commentary, vol. 1 (Philadelphia, PA: Jewish Publication Society, 1989), 109; Wenham, Genesis 1-15, 303-307; Joseph A. Fitzmyer, "'4QTestimonia' and the New Testament", in The Semitic Background of the New Testament, 59-89 (Grand Rapids, MI: Eerdmans, 1997), 64; Gerhard von Rad, Genesis. A Commentary, rev. ed. (Philadelphia, PA: The Westminster Press, 1972), 175. 
ic, is centered between the two. From this structure, the blessing of Melchizedek upon Abram becomes the crucial part of Genesis 14. The character of Melchizedek as the priest of God is easily identified here. However, not only is Melchizedek a priest, but also a king. Therefore, we should not disregard the importance of the components of the kingship of Melchizedek in Genesis 14 .

In the MT and the LXX, "king" ( $m l \square$ and basileōs) is used for the first time within the Pentateuch in Genesis 14, where it appears 27 times in the MT and 28 times in the $\operatorname{LXX}^{26}$. Considering that in Genesis it occurs 41 times in the MT and 45 times in the LXX, and in the entire Pentateuch 101 times in the MT and 103 times in the LXX, the frequency of "king" in Genesis 14 is surprising. Not only is this the chapter in which "king" appears for the first time, but also it is the chapter in which this word appears the most number of times within the Pentateuch. Thus, the crucial imagery of Genesis 14 is about kingship.

Melchizedek means "righteous king" or "my king is righteous". One's name indicates often one's character in the Ancient Near East texts. Thus, from his name, righteousness can be assumed to be one of the characters of Melchizedek.

He is the king of Salem. It is not certain whether or not Salem was the earlier name of Jerusalem, ${ }^{27}$ but it is evident that Salem refers to Jerusalem. Salem and Zion are parallel to each other in Psalms 76:3 (MT), and Jerusalem and Zion are also found in Psalms 51:20, 102:22, and 147:12 (MT). Thus, we see that Salem refers to Jerusalem. As for the shortened name, Nahum M. Sarna explains:

The reference to Salem in Psalm 76:3 is followed by a statement about the destruction of the weapon of war. This suggests that the shortened name of the city is a poeticism to produce the effect of shalom, "peace". "Jerusalem" has been reinterpreted to mean "city of peace", a symbol that later found expression in prophecy in such texts as Isaiah 2:1-5 and Micah $4: 1-4 .^{28}$

Lexicologically speaking, "Salem" comes from "peaceful". ${ }^{29}$ Thus Melchizedek, king of Salem, can be called "king of peace".

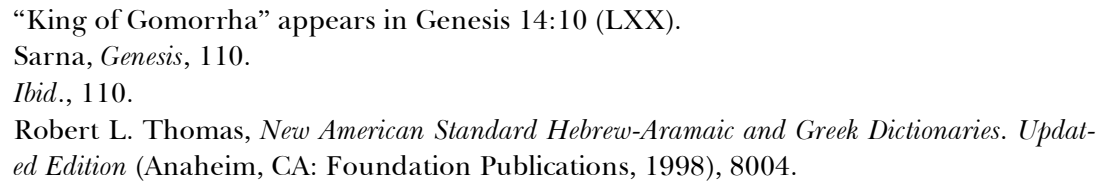


He stands in contrast to the other kings in Genesis 14. While the other kings fought each other, Melchizedek is a king of peace and a righteous one. In verses 17-24 as well, Melchizedek contrasts with the king of Sodom. Wenham observes that, whereas Melchizedek gives Abram bread and wine, the king of Sodom gives him nothing. ${ }^{30}$

As shown above, the context of Genesis 14 indicates the contrasts between Melchizedek and the other kings. While it is true that the blessing of Melchizedek upon Abram is a key point of Genesis 14, the characteristic of Melchizedek as a king of righteousness and peace, in contrast to the other kings, should not be overlooked.

\section{Psalm 110}

Psalm 110 is a royal psalm. It has been assumed to have been written for a coronation, and its date was probably during the early monarchic period. ${ }^{31}$ Of course, the term "king" is not mentioned anywhere in Psalm 110. However, the image which is used in Psalm 110 is evidently about the king. There are many connections between the images of Psalm 110 and the images of the kings of the Ancient Near East. Othmar Keel studies the relationship between Ancient Near Eastern iconography and the Book of Psalms. According to him, the Egyptian king was considered the divine son. ${ }^{32}$ A statue from Egypt portraying Pharaoh Horemheb (1345-1318 BC) sitting at the right hand of the king's god, Horus, ${ }^{33}$ and another statue from the exterior of the southern temenos-wall of the Djoser Pyramid at Sakkarah (3rd Dynasty, 2650-2600 BC) represent the king treading on a footstool, under which there are nine enemies. ${ }^{34}$ These images correspond with the image of the king in Psalms 110:1; "The LORD says to my Lord: 'Sit at my

30 Wenham, Genesis 1-15, 318.

31 D. W. Rooke, "Kingship as Priesthood: The Relationship between the High Priesthood and the Monarchy", ed. by John Day, King and Messiah in Israel and the Ancient Near East, JSOTSS 270 (Sheffield: Sheffield Academic Press, 1998), 188; Otherwise, G. Gerleman and M. C. Astour consider its date to be during the period of Maccabee; G. Gerleman, "Psalm cx", VT 31 (1981): 1-19; M. C. Astour, "Melchizedek", ed. by David Noel Freedman, The Anchor Bible Dictionary, vol. 4 (New York, NY: Doubleday, 1992), 684-686. S. Shreiner applies it to Joshua, the high priest of the Restoration period; "Psalm cx und die Investitur des Hohenpriesters", VT 27 (1977): 216-222. Othmar Keel, The Symbolism of the Biblical World. Ancient Near Eastern Iconography and the Book of Psalms, trans. Timothy J. Hallett (Winona Lake, IN: Eisenbrauns, 1997), 253. Ibid., 263.

34 Ibid., 255. 
right hand until I make your enemies a footstool for your feet"' (NIV). The "scepter from Zion" and "rule" (Psalms 110:2) are also images of kingship.

Psalms 110:3 has several textual issues. The MT is as follows:

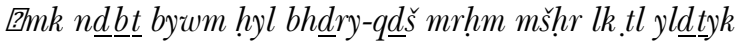

Your people will volunteer freely in the day of Your power; In holy array, from the womb of the dawn, Your youth are to You as the dew (NASB).

However, the LXX (Psalms 109:3) is as follows:

meta sou hē archē en hēmera tēs dunameōs sou en tais lamprtēsin tōn hagiōn, ek gastros pro heōsphorou exegennēsa se.

With you is dominion in the day of your power, in the splendours of the saints, I have begotten you from the womb before the morning. [translation and italics are mine]

The MT reads Zame $k \bar{a}$ ("your people") and the LXX as meta sou ("with you"),

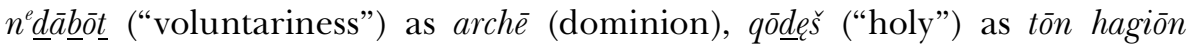
("the saints"), and yal' $\underline{d} \bar{u}$ Reyka ("your youth") as exegennēsa se ("I have begotten you"). And $l^{e} k \bar{a}$.tal does not exist in the LXX. We do not know exactly which reading is the original. However, as for Đam $k \bar{a}$ ("your people") and yal'd $\bar{u}$ Đeyka ("your youth"), from the context, the reading of the LXX appears to be more appropriate. Many scholars consider that Zame $k \bar{a}$ ("your people") and yal'du $\bar{u}$ Zeyka ("your youth") refer to the army of God and that verse 3 represents the cooperation between the king and his army for the holy war. ${ }^{35}$ However, the Lord conducts the war alone in verses 1-2 and 5-6. Thus, considering the people and the youth to be the troops is not appropriate for the context of this psalm. meta sou ("with you") and exegennessa se ("I have begotten you") are more appropriate. Many Hebrew manuscripts and the Syriac support this reading of the LXX. While the MT reads rẹhęm as temporal, that is, "the womb of the dawn", which means the very begin-

35 Leslie C. Allen, Psalms 101-50, WBC 21, rev. (Nashville: Thomas Nelson, 2002), 112; Willem A. VanGemeren, "Psalms", Psalms, Proverbs, Ecclesiastes, Song of Songs, The Expositor's Bible Commentary, ed. by E. Gaebelein, vol. 5 (Grand Rapids, MI: Zondervan, 1991), 698; Craig C. Broyles, Psalms, New International Biblical Commentary, vol. 11 (Peabody, MA: Hendricson, 1999), 414.

PERICHORESIS $10.1(2012)$ 
ning of the dawn, the LXX reads it as physical, that is, "the womb [of mother]". Because rẹhęm is never assigned a temporal meaning in the Old Testament, the reading of the LXX appears to be more appropriate.

If the reading of the LXX is correct, the image of kingship can be reinforced in Psalm 110 (LXX Psalms 109). Even if the reading of the LXX might not be the original, we should focus on the LXX because the author of Hebrews depended on the LXX rather than on the MT. The reading of meta sou hè archè en hèmera tēs dunameōs sou ("With you is dominion in the day of your power") rather than that of the MT reinforces that the king has the authority of ruling over the country. The reading of exegennesa se ("I have begotten you") indicates that the king has divine sonship. The concept of the divine sonship of the king appears also in Psalms 2:7 and 89:27, which are also royal psalms. Divine sonship was also a common aspect of divine kingship in the Ancient Near East, as shown above. Thus this reading of the LXX also reinforces the royal component of Psalm 110.

The king in Psalm 110 is a priest as well, according to Psalms 110:4. The concept of a priestly king was common in the Ancient Near East as we have already seen. But whether there was ever a priestly king in Israel is debatable. According to David R. Anderson, there is no sufficient evidence for this view. ${ }^{36}$ Israel's kings could be involved in worship (2 Samuel 6:14-18; 1 Kgs. $3: 3-4 ; 8: 22,54-55)$, but attempts by kings to perform priestly functions could be punished (1 Samuel 13:2-10; 2 Chronicles 26:16-21). As for this, John Goldingay explains:

Israelite kings did not undertake regular priestly acts such as offering sacrifices; when the Old Testament refers to kings offering sacrifices, usually it likely denotes their bringing sacrifices that the priests actually offered... They did not undertake priestly acts such as leading worship and prayer and blessing the people, and offered sacrifice on special occasions not covered by the regular rules. $^{37}$

From this explanation, we can see why Israel's kings who tried to perform priestly functions were punished. The reason they were punished is not because they were not priestly kings, but because they tried to function as priests even though there were already appointed priests who could per- 
form those services. Thus, Rooke considers royal priesthood in Israel not as a functional role, but as an ontological role. ${ }^{38}$ She states, "priesthood is primarily about doing things, about carrying out rituals and procedures, rather than about being a particular kind of person or having a particular genealogical descent" ${ }^{\prime 9}$ as a priestly king. In this sense and from the context, although it is true that Psalms 110:4 is about the eternal priest, it can be understood in light of the concept of royal priesthood.

It is crucial to interpret the meaning of kata tên taxin in verse 4. Most English versions translate taxin as "order" (ASV, ESV, KJV, NASB, NIV, RSV). The translation as "order" conveys a sense of "succession". The translation is not reasonable, because there is no reference to any king succeeding to the order of the priesthood of Melchizedek in the Old Testament. Thus Rooke suggests the translation "because of" or "for the sake of", ${ }^{40}$ John Goldingay, "after the manner of", ${ }^{41}$ and L. D. Hurst, "according to the character of". ${ }^{42}$ In my opinion, Hurst's translation is appropriate. He points out that the author of Hebrews paraphrases kata tên taxin Melchisedek in Psalms 109:4 (LXX) into kata tēn homoiotēta Melchisedek in Hebrews 7:15. If Christ succeeds to the order of the priesthood of Melchizedek, it is unacceptable, because Melchizedek is just an earthly king. Therefore kata tēn taxin Melchisedek in Psalms 109:4 (LXX) should be understood as "according to the character of in light of Hebrews 7:15", as Hurst's translation shows. What, then, is the character of Melchizedek? From the context of Psalm 110 , it is the character of the priestly king.

In Psalms 110:4, Yahweh has sworn an oath. Leslie C. Allen states, "A divine oath is especially associated with the Davidic covenant, in Psalms 89:4, 35-36 (3, 34-35); 132:11 (cf. 2 Samuel 3:9)" ${ }^{43}$ In this respect, the divine oath in Psalms 110:4 relates also to the Davidic covenant. Yahweh established the covenant with David (Psalms 89:29-30; 2 Samuel 7:13-16). The Davidic covenant is the promise of God regarding the eternity of the Davidic kingship. Thus the oath in Psalms 110:4 appears to emphasize the

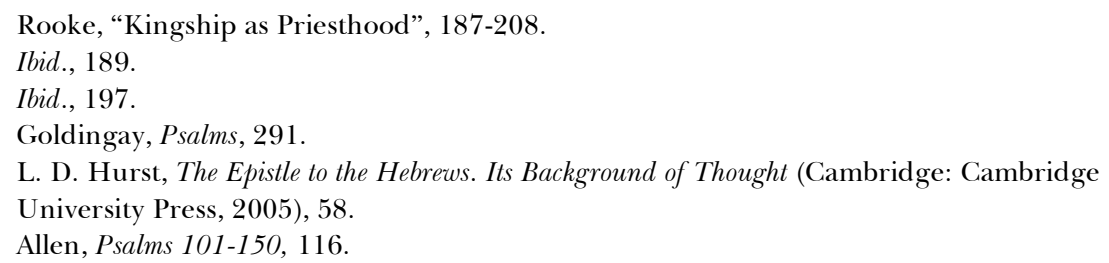

PERICHORESIS 10.1 (2012) 
eternal priestly kingship of David. Psalm 110:4 "is not about a priest who is being made king but about a king who is also being declared a priest". ${ }^{4}$

The components of kingship are also found in Psalms 110:5-7. The king will judge the nations and crush the rulers of the whole earth (verse 6). The imagery of these verses is of the victorious king as a warrior. As shown above, the image of the victorious king as a warrior is common in the divine kingship in the Ancient Near East.

\section{Connections between Genesis 14 and Psalm 110}

Horton says, "It seems impossible to establish any literary dependence between Genesis 14 and Psalms 90". ${ }^{45}$ He points out that the only two points of connection are "priest" and "Melchizedek". ${ }^{46}$ It is true that only the verbal connections are "priest" and "Melchizedek". However, other connections can also be considered. Geza G. Xeravits points out the following three: First, he says, "Both passages have an orientation towards Jerusalem". ${ }^{47}$ Salem in Genesis 14 correlates with Jerusalem, and Psalms 110:2 explicitly refers to Zion. Second, "In both texts, the priestly character of Melchizedek is closely connected (at least in their present form) with YHWH". Third, "Both texts contain-at least implicit-allusions to the kingship of Melchizedek". "Similar to the third connection, F. M. Cross states, "Both Genesis 14 and Psalm 110 are rooted in the royal ideology not in the priestly". ${ }^{49}$ From these, it appears that both passages focus on the priestly kingship rather than the priesthood of Melchizedek.

\section{Philo}

In Philo's works, Melchizedek is mentioned in Allegorical Interpretation III. 79-82 and in On Mating with the Preliminary Studies 99. Moreover, although the name "Melchizedek" does not appear, the epithet of Melchizedek is also found in On Abraham 235.

In Philo's work, Melchizedek is described predominantly as a priest. It is interesting to note that, although Melchizedek is not called "high priest" but just "priest" in Genesis 14, Philo called him "high priest" in Allegorical

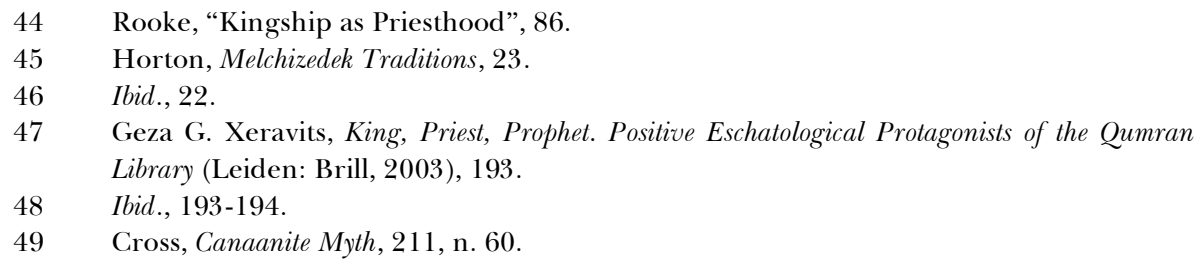


Interpretation III. 79. This epithet also appears in On Abraham. In On Abraham 235, the name Melchizedek does not appear, but the reference to "the great high priest of the most high God" designates Melchizedek evidently. When he beheld Abraham returning from the victory, Abraham "raised his hands to heaven", and "offered up sacrifices of thanksgiving for his victory" ${ }^{50}$ In On Mating with the Preliminary Studies 99, while Philo speaks of a tenth, Melchizedek was described as "a self-instructed and self-taught priesthood".

It is true that Melchizedek in Philo's work is described predominantly as a priest, but the component of kingship should not be overlooked. This component is dominant especially in Allegorical Interpretation III. 79-82, which describes how the king should be and what he should do. According to Philo, the king should not command, but persuade. He says, "(82) We may therefore call the tyrannical mind the ruler of war, and the kingly mind the guide to peace, that is Salem". Philo crafts Melchizedek an example of a king of peace. He emphasizes that Melchizedek is a lover of peace. He translates "Salem" as "peace". In addition to this, according to him, while the Ammonites and the Moabites were not willing to give bread and wine, Melchizedek gave bread and wine. Philo describes Melchizedek as an ideal king.

\section{Josephus}

In The Antiquities of the Jews I. 181, Josephus explains the story of Abram's encounter with Melchizedek. According to him, Abram met Melchizedek at a certain place called the king's dale. Melchizedek provided provisions in abundance for Abram's army, and blessed him. Abram gave Melchizedek the tithe of his prey, and he accepted the gift. Josephus emphasizes the hospitality of Melchizedek. He says, "Melchizedek supplied Abram's army in an hospitable manner, and gave them provisions in abundance" (italics mine). ${ }^{51}$ Josephus translates the name Melchizedek as "the righteous king", and considers the city of Salem to be Jerusalem.

In The Wars of the Jews VI. 438, Josephus mentions Melchizedek within the context of the history of the city of Jerusalem. According to Josephus, Melchizedek first built Jerusalem, which was formerly called Salem, and bridged (Peabody, MA: Hendrickson, 1996), 431.

51 Flavius Josephus and William Whiston, The Works of Josephus. Complete and Unabridged (Peabody, MA: Hendrickson, 1996), Antiquities, 1. 181. 
first built the temple there. According to Josephus, Melchizedek was the first priest of God, and the name Melchizedek means "righteous king".

\section{Qumran}

11QMelchizedek (11Q13)

11QMelchizedek was discovered in 1956. From fifteen fragments, three columns of the text were reconstructed. But in the first column only a few letters are preserved, and in the third only a few words are preserved. Only the second column, which contains 25 lines, is the most considerably preserved. ${ }^{52}$

The passage describes the year of Jubilee (2nd line). "Liberty shall be proclaimed for" the captives "in the first week of the jubilee which follows the ni[ne] jubilees" (6-7th lines). In "the d[ay of atone]ment" which "i[s] the e[nd of] the tenth [ju]bilee" and "the year of grace of Melchizedek", "atonement shall be made for all the sons of [light and] for the men [of] the lot of Mel[chi]zedek... accor[ding to] a[1l] their [wor]ks" (7-8th lines). In 11QMelchizedek, Melchizedek is in contrast to Belial. "Melchizedek will carry out the vengeance of Go[d's] judgements, [and on that day he will fr]e[e them from the hand of] Belial and from the hand of all the sp[irits of his lot]" (13th line).

Melchizedek is described as a heavenly figure. Even though he is called neither a king nor a priest in the extant text, his role can be assumed from the context. From the reference to the Day of Atonement as the year of grace of Melchizedek, the relationship between the atonement and Melchizedek as a priest can be assumed. At the same time, the role of Melchizedek as a king also can be assumed. He will win the war against Belial, and will set the captives free from the hand of Belial. This victory is reminiscent of the king's victory in Psalm 110. Eric F. Mason states, "A king in both Genesis 14 and Psalm 110, Melchizedek likewise is presented in the Qumran text as one who exercises authority over other heavenly beings and over his lot of humanity". ${ }^{53}$

As for the similarities between Melchizedek in 11QMelchizedek and Christ in Hebrews, Fred L. Horton points out the following five things: "1). Both Christ and Melchizedek are eschatological, redemptive figures. 2). Both are exalted in the heavens. 3). Both make atonement for sin. 4). Both 
overcome the forces opposed to God. 5). Both bring the promise of a new age" ${ }^{54}$ On the contrary, Hurst argues that there is little evidence of any connection between Melchizedek in 11QMelchizedek and Christ in Hebrews:

(a) The presentation of Jesus in Hebrews has virtually no military features. Jesus in Hebrews is basically a mediator, while the Melchizedek of Qumran has less to do with reconciliation than with the annihilation of enemies. (b) Auctor focuses on Melchizedek qua priest, whereas Qumran does not. (c) Remarkably, no clear allusion to either Genesis 14 or Psalms 110, the key texts of Hebrews 7, appears in 11Q Melch. Even more surprising is the complete omission of the texts quoted in 11Q Melch (Leviticus 25, Deuteronomy 15, Isaiah 52, 61, Psalms 7, 82:2) in Hebrews. "There is no overlapping". (d) Jesus' salvific work is accomplished in the heavenly sanctuary; the Qumran Melchizedek vanquishes Belial and his followers on earth. (e) The Jesus of Hebrews is fully a human being, while the Melchizedek of $11 \mathrm{Q}$ Melch is... an angelic being. (f) Whereas the primary feature of Melchizedek at Qumran is that he vanquishes his enemies, the primary point of Hebrews 7 is that Melchizedek and Jesus "abide". (g) At Qumran the work of Melchizedek still lies in the future, whereas Christ's work for his people is a present reality. (h) "In 11Q Melch he is directly related to levitical laws; in Hebrews stress is laid on his non-levitical status". ${ }^{55}$

From these similarities and differences, it is not easy to determine whether the author of Hebrews depended on the Qumran writings. As a matter of fact, the relationship between 11QMelchizedek and Hebrews has long been debated. Joseph. A. Fitzmyer, ${ }^{56}$ Y. Yadin,,${ }^{57}$ M. de Jonge, and A. S. Van der Woude ${ }^{58}$ argue that Hebrews 7 should be read in light of 11QMelchizedek. Fitzmyer continues that Melchizedek in 11QMelchizedek "as a heavenly redemption-figure make[s] it understandable how the author of the epistle to the Hebrews could argue for the superiority of Christ the

Horton, Melchizedek Traditions, 167.

Hurst, the Hebrews, 58-60.

Joseph. A. Fitzmyer, "Further Light on Melchizedek from Qumran Cave 11", in Essays on the Semitic Background of the New Testament (Missoula, MT: University of Montana, 1974), 267.

57 Y. Yadin, “A Note on Melchizedek and Qumran”, Israel Exploration Journal 15 (1965): $152-154$.

58 M. de Jonge and A. S. Van der Woude, "11QMelchizedek and the New Testament", New Testament Studies 12 (1966): 301-326. 
high priest over the levitical priesthood by appeal to such a figure" ${ }^{59} \mathrm{On}$ the contrary, Hurst ${ }^{60}$ and Rooke ${ }^{61}$ are skeptical about such a relationship. Even though it is not easy to determine the dependence of Hebrews on 11QMelchizedek, we can assume at least that the author of Hebrews knew of the idea of Melchizedek in the Qumran community and kept it in mind when he was writing.

1QApGen ar (1Q20) 22.12-17

The context of the story in 1QApGen ar 22.12-17 is similar to that of Genesis 14. Abram met Melchizedek at Shaveh, the Valley of the King, and Melchizedek brought out food and drink for Abram and for his men. Melchizedek blessed Abram, and Abram gave Melchizedek a tithe. The differences between Genesis 14 and 1QApGen ar are that in 1QApGen ar Salem is considered to be Jerusalem, and Shaveh, the Valley of the King, is called "the Valley of Bet ha-Kerem", ${ }^{62}$ that is, the Valley of the House of the Vineyard.

$4 Q 401$ fragment 11 and $4 Q 544$ fragments $2-3$

Another reference to Melchizedek in the Qumran texts appears in 4Q401 fragment 11, which is called 4QShirShabb, or Songs of the Sabbath Sacrifice. But this exists fragmentally, and the only reference to Melchizedek is that he was the "priest in the assem[bly of God]". ${ }^{3}$

Besides the Qumran texts mentioned above, Kobelski points out that another possible reference to Melchizedek can be assumed in 4Q544 (4Q Visions of Amram $^{\mathrm{b}}$ ar) fragments 2-3, which is an Aramaic text. 4Q544 fragment 2 is in parallel contrast to 4Q544 fragment 3. Thus Kobelski supposes this based on 4Q544 fragment 2-in which Melchireša' ("my king is wicked"), who is Belial, rules over all darkness-that the one who "rules [over all the sons of ligh]ht" in 4Q544 fragment 3 can be considered to be Melchizedek. ${ }^{64}$ Taken in conjunction with the war between Melchizedek and Belial in 11QMelchizedek, Kobelski's argument is likely, but it is not certain, since the extant text is too fragmentary. If Kobelski's assertion is

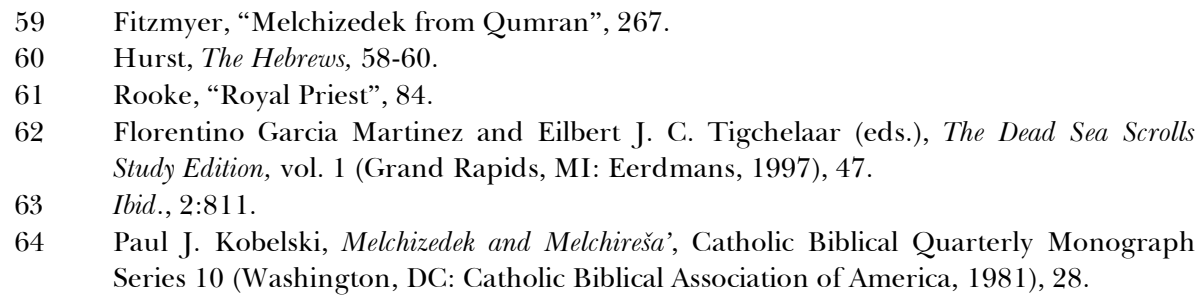


correct, we can see the component of the kingship of Melchizedek as the heavenly warrior in 4Q544.

To sum up the Qumran writings, Melchizedek is described not only as a priest but also as a warrior or king. James R. Davilla illustrates that "the eschatological "war in heaven' between the angelic forces of good and the demonic forces of evil was a topic of great interest" in Qumran, and it is related to "Melchizedek as the leader of the heavenly army". ${ }^{65}$ We cannot know whether the author of Hebrews depended on the Qumran writings or used them. However, if the author was familiar with the character of Melchizedek in the Qumran writings, as he was writing Hebrews he probably kept in mind the fact that in the Qumran writings Melchizedek is a king as well as a priest.

\section{The Old Testament Pseudepigrapha}

Jubilees 13:22-27

The Book of Jubilees is dated to about the second century BC. ${ }^{67}$ This passage deals with the account of Genesis 14. The law of tithing (13:25b-27) appears between Lot's being taken captive (13:23-25a) and the encounter between Abram and the king of Sodom (13:28-29). The law of tithing does not appear in Genesis 14:18-20. According to the Jubilees passage, "the Lord ordained [the tithe] as an ordinance forever that they should give it to the priests" (13:25). The order of the description in Jubilees 13:22-27 is similar to that of Genesis 14, yet there is no mention of Melchizedek.

Praeparatio Evangelica 9.17.4-6 (Pseudo-Eupolemus) ${ }^{68}$

Praeparatio Evangelica 9.17.4-6 probably dates from prior to the first century $\mathrm{BC}^{69}$ According to this passage, Abraham rescued his nephew, who was taken captive by the Armenians, and "took as captives the children and women of the enemy". Ambassadors tried to buy back the prisoners, and Abraham returned "those whom he had captured", but took nothing except for some food for his servants. The author converted Abraham's encounter with the king of Sodom in Genesis 14 into the conversation with the

65 James R. Davilla, "Melchizedek, Michael, and War in Heaven", in Society of Biblical Literature. 1996 Seminar Papers, 259-272 (Atlanta, GA: Scholars Press, 1996), 259.

66 James H. Charlesworth (ed.), The Old Testament Pseudepigrapha (New York, NY: Doubleday, 1985), 2:84.

$67 \quad$ Ibid., 2:44.

$68 \quad$ Ibid., 2:880.

$69 \quad$ Ibid., 2:873.

PERICHORESIS 10.1 (2012) 
ambassadors from the Armenians. "Abraham was treated as a guest by the city in the temple Argarizin, which means "mountain of the Most High'," and "received gifts from Melchizedek, its ruler and priest of God". The name of the temple, Argarizin, is grammatically unclear. ${ }^{70}$ Melchizedek is described to be the ruler of the city and the priest of God.

2 Enoch $71-73^{71}$

The date of 2 Enoch is uncertain. While Charles considers "that it was written by a Hellenized Jew in Alexandria in the first century BC" J. T. Milik "argues that it was written by a Christian monk in Byzantium in the ninth century AD". ${ }^{72}$ It is now almost impossible to determine its date because the book was collected and edited over a long period.$^{73} 2$ Enoch deals with the events from the life of Enoch up to the Flood. The first part (chapsters 1-68) describes Enoch's going up to the heavens, and the second part (chapters 69-73) portrays Enoch's successors, Methuselah, Nir, and Melchizedek.

The story of Melchizedek begins in chapter 71. Even though the priest Nir, the son of Lamech, did not sleep with his wife, Sopanim, she conceived and gave a birth to a son (71:2). When she died, the son came out of her womb, and he was like a three-year-old (71:18). The badge of priesthood was on his chest, and Nir and his brother, Noe, called his name Melkisedek (71:21). "When the child had been 40 days in Nir's tent" (72:1), God sent the archangel, Michael, to place Melkisedek "in the paradise of Edem" (72:5) before the Flood. "Melkisedek will be the head of the 13 priests who existed before", and, "in the last generation, there will be another Melkisedek, the first of 12 priests" (71:33-34). This other "Melkisedek will be the first priest and king in the city Salim in the style of [that] Melkisedek, the originator of the priests" (72:6). In 2 Enoch, Melchizedek is described not only as the first priest, but also as king in the city Salim, which probably corresponds to Salem in Genesis 14:18, but the dominant description is closer to that of priest rather than that of king.

\footnotetext{
Ibid., 2:880, n. m.

Ibid., 2:204-213.

Ibid., 1:95.

Ibid., 1:95.
}

PERICHORESIS $10.1(2012)$ 
Hellenistic Synagogal Prayers 12:6374

Hellenistic Synagogal Prayers dates from approximately AD 150 to AD 300. ${ }^{75}$ This prayer is about praising God who redeemed man. The author provides the reasons why God should be praised. God is "the maker of man, and the supplier of life, and the fulfiller of need, and the dispenser of laws" (12:56). In 12:63, God is described as "the one who appointed Melchizedek a high priest in [his] service". Melchizedek is very briefly described only as a high priest.

Summing up the Old Testament Pseudepigrapha, the description of Melchizedek is centered on his being a priest rather than a king, even though he is described as a ruler in Praeparatio Evangelica and as a king in 2 Enoch. However, it is difficult to investigate his character in the Old Testament Pseudepigrapha in relationship to Hebrews. Mentions of Melchizedek in most of the writings are too brief, and although the discussion of Melchizedek in 2 Enoch is abundant, it is not easy to determine the relationship between 2 Enoch and Hebrews due to its uncertain and complicated date.

\section{Hebrews 7}

In Hebrews 7, the main argument is that Christ is superior to the Levitical priesthood. The author of Hebrews understands Melchizedek to be the model of the superiority of Christ over the Levitical priesthood. The author of Hebrews writes that Melchizedek was the king of Salem and the priest of God Most High (Hebrews 7:1). When Abraham met Melchizedek, Abraham gave him a tenth of everything, and Melchizedek blessed Abraham (Hebrews 7:2). Melchizedek is superior to Abraham, because Melchizedek blessed Abraham, as the greater blesses the lesser (Hebrews 7:7) and Abraham gave him a tenth (Hebrews 7:6). Thus, according to the author, Christ in the order of Melchizedek is superior to the Levitical priesthood in the order of Aaron, because the descendant of Levi was in the body of Abraham (Hebrews 7:10).

Horton points out that, even though Jethro was not only a priest but also without father or mother and without a genealogy, like Melchizedek, the reason the author of Hebrews selected Melchizedek to be the model was because "Melchizedek is the first priest mentioned in the Torah". ${ }^{76}$ As shown above, this view is supported by Josephus's work, The Wars of the Jews VI.

Ibid., 2:693.

Ibid., 2:673

Horton, Melchizedek Traditions, 157.

PERICHORESIS 10.1 (2012) 
438, in which Melchizedek was described as the first priest of God. However, this was not likely the reason, because the author of Hebrews does not mention Melchizedek as the first priest. Although not called a priest, Abel could also be considered the first priest. ${ }^{77}$ If the fact that Melchizedek as the first priest of God is important in Hebrews, the author of Hebrews should have mentioned it. But there is no allusion to that fact. Rather, the reason the author of Hebrews portrays Melchizedek as the model for Christ's priesthood is because his priesthood is a royal priesthood, which is different from the high priesthood. Rooke states, "the most important point to note is that writer's choice of Melchizedek as the model for Christ's priesthood has in itself royal overtones" ${ }^{78}$ According to her:

The characteristics of Jesus's priesthood which are enumerated in the extended description of him as "priest after the order of Melchizedek" are those not merely of high priesthood but of royal priesthood; in other words, rather than being the description of a high priest, the picture of Jesus given in Hebrews 7 depicts what modern scholarship would call a sacral king. ${ }^{79}$

The royal components of Melchizedek can be found first in Hebrews $7: 1-3$. The structure is as follows: ${ }^{80}$

\begin{tabular}{|c|c|c|}
\hline $7: 1$ & $\begin{array}{l}\mathrm{a} \\
\mathrm{b}\end{array}$ & $\begin{array}{l}\text { Houtos gar ho Melchisedek, } \\
\text { basileus Salēm. }\end{array}$ \\
\hline & $\mathrm{c}$ & hireus tou theou tou hyphistou, \\
\hline & d & $\begin{array}{c}\text { ho synantēsas Abraham ypostrephonti apo tēs kopēs tōn Basileōn } \\
\text { (royal) }\end{array}$ \\
\hline & $\mathrm{e}$ & kai eulogēesas auton, \\
\hline $7: 2$ & $\mathrm{a}$ & $\begin{array}{r}\text { hō kai dekatēn apo pantōn emerisen Abraham, } \\
\text { (priestly) }\end{array}$ \\
\hline & $\mathrm{b}$ & $\begin{array}{r}\text { pōton men hermēveuomenos dikaiosynēs epeita } \\
\text { (royal) }\end{array}$ \\
\hline & $\mathrm{c}$ & $\begin{array}{r}\text { de kai basileus Salēm, ho estin basileus eirēnēs, } \\
\text { (royal) }\end{array}$ \\
\hline 7.9 & $\mathrm{a}$ & $\begin{array}{l}\text { apatōr amētōr agenealogētos, mète archēn hēmerōn mète zōess telos } \\
\text { echōn, }\end{array}$ \\
\hline
\end{tabular}


b aphōmoiōmenos de tō huiō tou theou, (royal)

c menei hiereus eis to diēnekes.

The main clause in Hebrews 7:1-3 is "Houtos gar ho Melchisedek... mevei hiereus eis to diēnekes" (Hebrews 7:1a and 7:3c). Hebrews 7:1b-3b describes who Melchizedek is, and provides the grounds for the eternity of Melchizedek as priest. Rooke points out that the characteristics of Hebrews 7:1b-3b are "the constituent elements of his identity", and thus, "without them, he could not be an eternal priest, but with them he cannot fail to be". "This Melchizedek, inasmuch as all these things are true of him, remains a priest forever". 82

In Hebrews 7:1b-3b, many more royal components can be found compared to priestly components. In Hebrews 7:1b, basileus Salèm is a clearly royal component. On the contrary, it is not easy to determine the main feature of Hebrews 7:1d. But when we consider the context of Genesis 14, we can assume that Hebrews 7:1d has a royal, rather than a priestly, component. As shown above, Melchizedek stands in direct contrast to the other kings in Genesis 14. The sentence, apo tēs kopēs tōn basileōn ("from the slaughter of the kings"), is reminiscent of the context of Genesis 14, in which the kings are bellicose, in contrast to Melchizedek. In this respect, Hebrews $7: 1 \mathrm{~d}$ conveys a royal, rather than a priestly, component.

In Hebrews 7:2b-c, the author of Hebrews translates the name Melchizedek as "righteous king", and the name of Salem as "peace". These translations appear also in Philo, Allegorical Interpretation III. 82, and in Josephus' The Antiquities of the Jews I. 181, as shown above. According to the interpretation of the author of Hebrews, righteousness and peace are the characteristics of Melchizedek. ${ }^{83}$ This "character is shown to be that of a king "in whom and through whom righteousness and peace are realized'." ${ }^{84}$ They are also very important characteristics of the divine kings in the Ancient Near East, as shown above. In the Old Testament, righteousness and peace are crucial virtues for the ideal king (Psalms 72). The fact that the author of Hebrews translated the names Melchizedek and Salem as "righteousness"

Ibid., 88 .

Ibid., 88

Ibid., 85 .

David Peterson, Hebrews and Perfection. An Examination of the Concept of Perfection in the "Epistle to the Hebrews" (Cambridge: Cambridge University Press, 1982), 106.

PERICHORESIS 10.1 (2012) 
and "peace" respectively indicates that the royal components are emphasized in the verse.

As for Hebrews 7:3a, many scholars believe that the author of Hebrews took into consideration the fact that there is no reference to the father, the mother or the genealogy of Melchizedek in Genesis $14 .^{85}$ However, apatō amètōr ("without father without mother") is more likely to be reminiscent of the divine kingship in the Ancient Near East as shown above. Because the king was of divine origin from birth in the Ancient Near East, he was considered to be "the one who has neither father nor mother" keinen Vater, der dich erzeugt hat, unter den Menschen,... du hast keine Mutter, die dich geboren hat, unter den Menschen", ${ }^{87}$ "He! Halloh! Ich rufe es dir zu, dieses Halloh, mein Vater! Du hast keine menschlichen Mütter". ${ }^{88}$ Gudea, who was the king of Lagash in Southern Mesopotamia from ca. 2144 to 2124 BC said to the Sumerian goddess Gatumdug, "I have no mother, thou art my mother, I have no father, thou art my father" ${ }^{8}$ Aššurbanipal, king of Assyria (669-c.630 BC), said also to the Sumerian goddess Ninlil, "I am thy servant, Aššrbanipal whom thy hands formed without father and mother" ${ }^{90}$ These sources demonstrate that the concept of the king having "no father and no mother" was common as a prerequisite for divine kingship in the Ancient Near East. Thus, the lack of a father and mother in Hebrews 7:3a for Melchizedek suggests a royal component in this portion of the verse as well.

In Hebrews 7:3b, Melchizedek is like the "son of God". This is another royal component. As shown above, the divine king was called "son of god" in the Ancient Near East. In the Old Testament, too, the king was called "son of God" (Psalms 2:7; 89:27). Thus the royal component can be found also in Hebrews 7:3b.

Joseph A. Fitzmyer, “'Now this Melchizedek...' (Hebrews 7:1)”, Catholic Biblical Quarterly 25.3 (1963): 316; Bruce, the Hebrews, 137-138; H. W. Montefiore, A Commentary on the Epistle to the Hebrews (Peabody, MA: Hendrickson, 1987), 119; R. McL. Wilson, Hebrews (Grand Rapids, MI: Eerdmans, 1987), 122; Paul Ellingworth, The Epistle to the Hebrews. A Commentary on the Greek Text (Grand Rapids: Eerdmans, 1993), 357-358.

86 Engnell, Divine Kingship, 4.

87 K. Sethe, Die Altägyptischen Pyramidentexte 3 (Leipzig: Wissenschaftliche Buchgesellschaft, 1908), 208, quoted in Engnell, Divine Kingship, 4.

88 G. Roeder, Urkunden zur Religion des alten Ägypten (Jena, 1915), 186, quoted in Engnell, Divine Kingship, 5.

89 Engnell, Divine Kingship, 16, n. 7.

$90 \quad$ Ibid., 16, n. 7. 
From these descriptions we see that the author of Hebrews emphasized not only the priestly components, but also the royal components of Melchizedek in Hebrews 7:1-3. If the author of Hebrews focused only on the priesthood of Melchizedek, such many descriptions of Melchizedek as king might not have been needed. The fact that the author of Hebrews provides the description of Melchizedek as king more than as priest in Hebrews 7:1-3 gives a sense that the author seemed to choose Melchizedek as the model for Christ because of his royal priesthood.

In Hebrews 5:6, 7:17, and 7:21, Psalms 110:4 is quoted. There are also allusions to Psalms 110:4 in Hebrews 5:10, 6:20, 7:11. As shown above, kata tên taxin should be translated as "according to the character". Christ is defined as a high priest forever according to the character of Melchizedek. The character indicates the royal priesthood of Melchizedek.

Rooke sees also the royal component from the expression that Christ descended from Judah (Hebrews 7:14). ${ }^{91}$ The line of the kingship of David came from the tribe of Judah. "From Judah" is in contrast to the Levitical priesthood. Thus, in the expression "from Judah", the royal component also can be found in Hebrews 7:14.

Hebrews 7 ends with a comparison between the high priests according to the law and Christ according to the oath (verse 28). Paul Ellingworth paraphrases Hebrews 7:28b; "[God's] oath establishes [as high priest] forever the one who [already] has the status of [God's] Son". ${ }^{92}$ We should pay attention to the fact that, while "high priest" is expected rather than "[God's] Son" in Hebrews 7:28b, the author omits "high priest", and instead uses "[God's] Son". "[God's] Son" is a royal component, as shown above. From the fact that the author intentionally omits "high priest", and instead uses "[God's] Son" in Hebrews 7:28b, we can notice that while the author focuses on Christ as high priest—-thus superior to the Levitical priests-he still keeps in mind Christ as a king in Hebrews 7.

Hebrews 8:1-2 functions as a transition from Hebrews 7 to Hebrews 8-9. While chapter 7 focuses on the royal priesthood of Christ, chapters 8-9 focus on the sacrifice and heavenly sanctuary of Christ. The issue in 8:1 is how to interpret Kephalaion. While the KJV and NASB appear to translate it as the summary of the preceding passage, the ASV, ESV, NIV, and RSV appear to translate it as the main point of the following passage. Many scholars agree that it should be interpreted as the "main point" for the fol-

91 Rooke, "Royal Priest”, 89

92 Ellingworth, The Hebrews, 397.

PERICHORESIS 10.1 (2012) 
lowing argument. However, it also functions as the development of Hebrews 7. Ellingworth points out that "7:28 and 8:1 are thus bound together by a kind of osmosis; in 7:28, where we expect "high priest" we have "Son", and in 8:1 we have the reverse" ${ }^{93}$ George H. Guthrie states, "Hebrews 8:1-2 functions as a direct intermediary transition between 5:1-7:28 and 8:310:18". ${ }^{94}$ According to him, Hebrews 8:1, except en tois ouravois, refers to what has been written so far. That is, Hebrews 8:1-2 functions not only as a summary of the previous argument, but also as an introduction of the next section. The previous argument includes the contents of Hebrews 7. Thus, if Hebrews 8:1-2 functions as a summary of the previous argument, we can see the components of Hebrews 7 in Hebrews 8:1-2. In Hebrews 8:1, the author describes Christ as "high priest, who sat down at the right hand of the throne of the Majesty in heaven" (NIV). The expression "sitting down at the right hand of the throne of the Majesty" includes a royal component, as shown above. Here again, we see that, while the author focused on Christ as a priest, he was keeping in mind the royal priesthood, even in Hebrews 7 .

\section{Royal Priesthood in Hebrews}

The character of royal priesthood of Christ can be seen also throughout the letter to the Hebrews. In Hebrews 1:3, the Son had made purification for sins, and had sat down at the right hand of the Majesty on high. There can be seen not only the character of the priest but also of the king. The purification for sins indicates the role of the priest. The title "Son" is the royal component as shown above. Sitting the right hand of the Majesty on high alludes to Psalms 110:1 ${ }^{95}$ and indicates the Son as the king as shown above.

Hebrews 3:1-6 offers a comparison of Moses and Christ. As Moses was faithful in all God's house, Christ was also. In this paragraph, the title of Christ begins with "priest" in verse 1, but ends with "the Son" in verse 6 . From this, the royal priesthood of Christ can also be seen. One thing with which we should deal is about the interpretation of oikos (God's house). Because this paragraph begins with the title of high priest in verse 1 , the house appears to represent the tabernacle or the sanctuary. But it is neither the

Ibid., 398.

George H. Guthrie, The Structure of Hebrews. A Text-Linguistic Analysis (Grand Rapids, MI: Baker Books, 1994), 106.

95 George H. Guthrie, "Hebrews", Commentary on the New Testament Use of the Old Testament, ed. By G. K. Beale and D. A. Carson, 919-996 (Grand Rapids, MI: Baker Academic, 2007), 924.

PERICHORESIS $10.1(2012)$ 
tabernacle nor the sanctuary. It is the people of God. ${ }^{96}$ Hebrews 3:5 alludes to Numbers 12:7; "But this is not true of my servant Moses; he is faithful in all my house" (NIV). According to the context, the house in Numbers 12:7 is the community. Moreover, the other words are used for the sanctuary and the tabernacle in Hebrews. hagios is used for the sanctuary (Hebrews $8: 2 ; 9: 1 ; 10: 19 ; 9: 2,8,12,24,25 ; 13: 11)$, and skêne for the tabernacle (Hebrews $8: 2,5 ; 9: 2,3,6-9,11,21)$. The author of Hebrews also says clearly in verse 6; "we are his house". It means that God's house indicates the people of God. If the house is the tabernacle, it could connect with the priest, but the house as the community reinforces the Son as the king who rules over the people of God.

In 4:14, Christ is described not only as great high priest but also as the Son of God. It is another example for the royal priesthood of Christ.

In 5:5-6, the author of Hebrews quotes Psalms 2:7 and Psalms 110:4 to support that Christ is the high priest. The two quotations are not only about the priest. Psalms 2:7 is more likely about the character of the king, and Psalms 110:4 includes both characters as shown above. It means that Christ as the high priest is also king. Although the direct reference indicates that Christ is the high priest, the high priest is also the king according to the quotation. Ellingworth appears to acknowledge this; in that for him "The purpose of verses $5 \mathrm{f}$. is to bind together the titles of Son and (high) priest as being equally conferred on Christ by god, as scripture attests". ${ }^{97}$ The author of Hebrews concludes the paragraph about Christ as the high priest in Hebrews 5:10. As shown above, kata tên taxin in the verse should be translated as "according to the character". That is, Christ is the high priest according to the character of Melchizedek. The character indicates the royal priesthood of Melchizedek. Thus Christ in Hebrews 5:5-6 has not only the characteristics of the priest but also those of the king.

We can see the combined character in Hebrews 10:12-13 as well. Its context is about Christ's sacrifice once for all. While the sacrifice by law should be offered again and again and "can never take away sins", Christ "had offered for all time one sacrifice for sins" (NIV). We can see him as a highpriest. And then "he sat down at the right hand of God", and "waits for his enemies to be made his footstool" (NIV) in Hebrews 10:12-13. Even though they are not direct quotations, they are based on Psalms 110:1. ${ }^{98}$ As

Ellingworth, The Hebrews, 210.

Ibid., 281.

Guthrie, "Hebrews", 978.

PERICHORESIS 10.1 (2012) 
shown above, they are part of the royal components. That is, Christ is described as not only a priest, but also a king in Hebrews 10:12-13.

In 10:21, Christ is described as "a great priest over the house of God" (NIV). Then, what is the house of God? As shown above, the house of God is used for the people of $\operatorname{God}^{99}$ as in Hebrews 3:1-6. Even though there is no verb, epi ton oikon tou theou ("over the house of God") implies that he rules over the people of God. In this sense, it is closer to the royal component rather than to the priestly one. If this is true, although it seems to be obscure, the characteristics of Christ being not only a priest but also a king can be found in Hebrews 10:21 as well.

To sum it up, the author of Hebrews describes Christ not only as a priest but also as a king throughout Hebrews. Thus, his priesthood is not simply implied as a part of the priesthood, but as part of the royal priesthood.

\section{Conclusion}

I began this paper to address the problem regarding how the royal component of Melchizedek in Hebrews 7 was disregarded, as Rooke points out. In order to investigate the royal component of Melchizedek in Hebrews 7, I studied divine kingship in the Ancient Near East and the royal components of Melchizedek in the Old Testament and in the Second Temple writings. From the study of divine kingship in the Ancient Near East, I discovered that the images of divine kingship in the Ancient Near East continue in Psalm 110 and Hebrews 7: "divine sonship", "sitting at the right hand", "no father and no mother", and so on. Based on research of the context of Genesis 14 and Psalm 110, which focus on the priestly kingship, I suggested that when the author of Hebrews quotes from Genesis 14 and Psalm 110 about Melchizedek, the passages in Hebrews should be understood in light of the context of the source passages. In the Second Temple writings, I found components of the kingship of Melchizedek. Even though Melchizedek was described as priest rather than king in the Old Testament Pseudepigrapha, it is hard to determine the relationship between these writings and Hebrews because their descriptions of Melchizedek are too brief and their dates are uncertain.

Finally, I could draw the royal components of Melchizedek in Hebrews 7. It is evident that the author of Hebrews focused on the superior priesthood of Christ by using Melchizedek as a model for Christ in Hebrews 7. As 
the priesthood of Melchizedek is a royal priesthood, the priesthood of Christ is also a royal priesthood. The royal priesthood of Christ can also be seen in that the character of priest and king has been combined into Christ throughout Hebrews (Hebrews 1:3; 3:1-6; 4:14; 5:5-6; 10:12-13, 21). Therefore, with the priesthood of Melchizedek considered a royal priesthood, the royal priesthood of Christ should not be neglected in Hebrews 7.

\section{Bibliography}

Allen, Leslie C. Psalms 101-50. Word Biblical Commentary 21. Revised Edition. Nashville, TN: Thomas Nelson, 2002.

Anderson, David R. The King-Priest of Psalm 110 in Hebrews. New York: Peter Lang, 2001.

Aschim, Anders. "Melchizedek the Liberator: An Early Interpretation of Genesis 14?” Society of Biblical Literature. 1996 Seminar Papers, 243-258. Atlanta, GA: Scholars Press, 1996.

"Melchizedek and Jesus: 11Q Melchizedek and the Epistle to the Hebrews". Edited by Carey C. Newman, James R. Dvila, and Gladys S. Lewis. The Jewish Roots of Christological Monotheism. Papers from the St. Andrews Conference on the Historical Origin of the Worship of Jesus. Leiden: Brill, 1999, 129-147.

. "Melchizedek and Levi". The Dead Sea Scrolls. Fifty Years after Their Discovery 1947-1997. Edited by L. H. Schiffman, E. Tov, and J. C. VanderKam. Jerusalem: Israel Exploration Society, 2000, 773-788.

Astour, M. C. "Melchizedek". The Anchor Bible Dictionary. Edited by David Noel Freedman. Volume 5. New York, NY: Doubleday, 1992.

Bird, Chad L. "Typological Interpretation within the Old Testament: Melchizedekian Typology". Concordia Journal 26 (2000): 36-52.

Broyles, Craig C. Psalms. New International Biblical Commentary. Volume 11. Peabody, MA: Hendricson, 1999.

Bruce, F. F. The Epistle to the Hebrews. Grand Rapids, MI: Eerdmans, 1990.

Charlesworth, James H, ed. The Old Testament Pseudepigrapha. Volumes 1-2. New York, NY: Doubleday, 1985.

Cockerill, Gareth Lee. The Melchizedek Christology in Hebrews 7:1-28. Diss., Union Theological Seminary: Virginia, 1976. "Melchizedek or 'King of Righteousness'?” Evangelical Quarterly 63 (1991): 305-312. 
Contenau, Georges. Everyday Life in Babylon and Assyria. New York, NY: St. Martin's Press, 1954.

Cross, Frank Moore. Canaanite Myth and Hebrew Epic. Essay in the History of the Religion of Israel. Boston, MA: Harvard University Press, 1973.

Davilla, James R. "Melchizedek, Michael, and War in Heaven". Society of Biblical Literature. 1996 Seminar Papers. Atlanta, GA: Scholars Press, 1996, 259-272.

"Melchizedek, the 'Youth', and Jesus". In Dead Sea Scrolls as Background to Postbiblical Judaism and Early Christianity. Edited by James R. Davila. Leiden: Brill, 2003, 248-274.

De Jonge, M. and A. S. Van der Woude. "11QMelchizedek and the New Testament”. New Testament Studies 12 (1966): 301-326.

Delcor, M. "Melchizedek from Genesis to the Qumran texts and the Epistle to the Hebrews". Journal for the Study of Judaism in the Persian, Hellenistic and Roman Period 2 (1971): 115-135.

Dunnell, John. Covenant and Sacrifice in the Letter to the Hebrews. Cambridge: Cambridge University Press, 1992.

Ellingworth, Paul. The Epistle to the Hebrews. A Commentary on the Greek Text. Grand Rapids, MI: Eerdmans, 1993.

Engnell, Ivan. Studies in Divine Kingship in the Ancient Near East. Oxford: Basil Blackwell, 1967.

Fitzmyer, Joseph A. “'Now this Melchizedek...' (Hebrews 7:1)”. Catholic Biblical Quarterly 25.3 (1963): 305-321.

. "Futher Light on Melchizedek from Qumran Cave 11". Essays on the Semitic Background of the New Testament. Missoula, MT: University of Montana, 1974.

. "4QTestimonia' and the New Testament". The Semitic Background of the New Testament, 59-89. Grand Rapids, MI: Eerdmans, 1997. 69.

. "Melchizedek in the MT, LXX, and the NT". Biblica 81 (2000): 63-

Gammie, John G. "Loci of the Melchizedek Tradition of Genesis 14:18-20". Journal of Biblical Literature 90.4 (1971): 385-396.

Gerleman, G. "Psalm cx". VT 31 (1981): 1-19.

Goldingay, John. Psalms. Psalms 90-150. Volume 3. Grand Rapids, MI: Baker Academic, 2008.

Gurney, O. R. Some Aspects of Hittite Religion. Oxford: Oxford University Press, 1976. 
Guthrie, George H. The Structure of Hebrews. A Text-Linguistic Analysis. Grand Rapids, MI: Baker Books, 1994.

. "Hebrews". Commentary on the New Testament Use of the Old Testament. Edited by Beale, G. K. and D. A. Carson, 919-996. Grand Rapids, MI: Baker Academic, 2007.

Horton, Fred L. Jr. The Melchizedek Traditions. A Critical Examination of the Sources to the Fifth Century AD and in the Epistle to the Hebrews. Cambridge: Cambridge University Press, 1976.

Hurst, L. D. The Epistle to the Hebrews. Its Background of Thought. Cambridge: Cambridge University Press, 2005.

Josephus, Flavius and William Whiston. The Works of Josephus. Complete and Unabridged. Peabody, MA: Hendrickson, 1996.

Keel, Othmar. The Symbolism of the Biblical World. Ancient Near Eastern Iconography and the Book of Psalms. Translated by Timothy J. Hallett. Winona Lake, IN: Eisenbrauns, 1997.

Kobelski, Paul J. Melchizedek and Melchireša'. Catholic Biblical Quarterly Monograph Series, 10. Washington, DC: Catholic Biblical Association of America, 1981.

Koester, Craig R. Hebrews. A New Translation with Introduction and Commentary. The Anchor Bible. Volume 36. New York, NY: Doubleday, 2001.

Langdon, S. Die Neubabylonischen Königsinschriften. Vorderasiatische Bibliothek 4. Leipzig: J. C. Hinrichs, 1912.

Lefler, N. "The Melchizedek Traditions in the Letter to the Hebrews: Reading through the Eyes of an Inspired Jewish-Christian Author". Pro Ecclesia 16.1 (2007): 73-89.

Luria, Ben Zion. "Melchizedek, King of Salem, Priest of El Elyon". Beit Mikra 32 (1986): 1-3.

Margalith, Othniel. "The Riddle of Genesis 14 and Melchizedek". Zeitschrift für die alttestamentliche Wissenschaft 112 (2000): 501-508.

Martinez, Florentino Garcia and Eilbert J. C. Tigchelaar, eds. The Dead Sea Scrolls Study Edition. Volumes1-2. Grand Rapids, MI: Eerdmans, 1998.

Mason, Eric F. "Hebrews 7:3 and the Relationship between Melchizedek and Jesus". Biblical Research 50 (2005): 41-62.

. "You Are a Priest Forever". Second Temple Jewish Messianism and the Priestly Christology of the Epistle to the Hebrews. Leiden: Brill, 2008.

McConville, J. Gordon. "Abraham and Melchizedek: Horizons in Genesis 14". He Swore an Oath. Biblical Themes from Genesis 12-50. Edited by Rich- 
ard S. Hess, Gordon J. Wenham, and Philip E. Satterthwaite, 93-118. Carlisle: Paternoster, 1994.

McCullough, John C. "Melchizedek's Varied Role in Early Exegetical Tradition". Near East School of Theology Theological Review 1.2 (1978): 52-66.

McNamara, Martin. "Melchizedek: Genesis 14:17-20 in the Targums, in Rabbinic and Early Christian Literature". Biblica 81.1 (2000): 1-31.

Merrill, Eugene H. "Royal Priesthood: An Old Testament Messianic Motif". Bibliotheca Sacra 150 (1993): 50-61.

Montefiore, H. W. A Commentary on the Epistle to the Hebrews. Peabody, MA: Hendrickson, 1987.

Nahum Sarna. Genesis. JSP Torah Commentary. Volume 1. Philadelphia, PA: Jewish Publication Society, 1989.

Nel, P. J. "Psalm 110 and the Melchizedek Tradition". Journal of Northwest Semitic Languages 22.1 (1996): 1-14.

Paul, M. J. "The Order of Melchizedek (Psalms 110:4 and Hebrews 7:3)". The Westminster Theological Journal 49 (1987): 195-211.

Pearson, Birger A. "Melchizedek in Early Judaism, Christianity, and Gnosticism". Biblical Figures outside the Bible. Edited by Michael E. Stone and Theodore A. Bergren, 176-202. Harrisburg, PA: Trinity Press International, 1998.

Peterson, David. Hebrews and Perfection. An Examination of the Concept of Perfection in the "Epistle to the Hebrews". Cambridge: Cambridge University Press, 1982.

Philo of Alexandria and Charles Duke Yonge. The Works of Philo. Complete and Unabridged. Peabody, MA: Hendrickson, 1996.

Rainbow, Paul A. "Melchizedek as a Messiah at Qumran". Bulletin for Biblical Research 7 (1997): 179-194.

Roeder, G. Urkunden zur Religion der alten Ägypter. Jena, 1915.

Rooke, Deborah. W. "Kingship as Priesthood: The Relationship between the High Priesthood and the Monarchy". King and Messiah in Israel and the Ancient Near East. Edited by John Day, 187-208. Sheffield: Sheffield Academic Press, 1998.

. "Jesus as Royal Priest: Reflections on the Interpretation of the Melchizedek Tradition in Hebrews 7". Biblica 81.1 (2000): 81-94.

Rowley, H. H. "Melchizedek and Zadok (Genesis 14 and Psalms 110)". Edited by Walter Baumgarten. Festschrift für Alfred Bertholet zum 80. Geburtstag. (Tübingen: Mohr-Siebeck, 1950). 
Sethe, K. Die Altägyptischen Pyramidentexte 3. Leipzig: Wissenschaftliche Buchgesellschaft, 1908.

Shreiner, S. "Psalm cx und die Investitur des Hohenpriesters". VT 27 (1977): 216-222.

Thomas, Robert L. New American Standard Hebrew-Aramaic and Greek Dictionaries. Updated Edition. Anaheim, CA: Foundation Publications, 1998.

Tsumura, David Toshio. "King and Cults in Ancient Ugarit". Priests and Officials in the Ancient Near East. Edited by Kazuko Watanabe. Heidelberg: Universitätsverlag C. Winter, 1999, 213-238.

VanGemeren, Willem A. "Psalms". Psalms, Proverbs, Ecclesiastes, Song of Songs. Edited by E. Gaebelein. The Expositor's Bible Commentary 5. Grand Rapids, MI: Zondervan, 1991, 1-880.

Von Rad, Gerhard. Genesis. A Commentary. Revised edition. Philadelphia, PA: The Westminster Press, 1972.

Wenham, Gordon J. Genesis 1-15. Word Biblical Commentary. Volume 1. Dallas, TX: Word, 2002.

Wilson, R. McL. Hebrews. Grand Rapids, MI: Eerdmans, 1987.

Xeravits, Geza G. King, Priest, Prophet. Positive Eschatological Protagonists of the Qumran Library. Leiden: Brill, 2003.

Yadin, Yigael. "A Note on Melchizedek and Qumran". Israel Exploration Journal 15 (1965): 152-154.

"The Dead Sea Scrolls and the Epistle to the Hebrews". Scripta Hierosolymitana, Edited by Chaim Rabin and Yigael Yadin. Volume 4. Jerusalem: Magnes Press, 1965, 36-55. 